\title{
A synthesis of the enethiols of thioacylsilanes by the reaction of dimethyl(phenyl)silyllithium with $N, N$-dimethylthioamides
}

\author{
Marina Buswell and Ian Fleming* \\ Department of Chemistry, Lensfield Road, Cambridge CB2 1EW, UK \\ E-mail: if10000@cam.ac.uk
}

Dedicated with affection to Professor S. V. Kessar on the occasion of his $\mathbf{7 0}^{\text {th }}$ birthday

(received 20 May 02; accepted 19 Jun 02; published on the web 27 Jun 02)

\begin{abstract}
$\mathrm{N}, \mathrm{N}$-Dimethylthioamides react with dimethyl(phenyl)silyllithium to give the enethiols of thioacylsilanes.
\end{abstract}

Keywords: Dimethyl(phenyl)silyllithium reagent, acylsilanes, thioacylsilanes, Brook rearrangement

\section{Introduction}

We reported earlier that $N, N$-dimethylamides 1 react with dimethyl(phenyl)silyllithium to give three different types of product, all in high yield, depending upon the conditions under which the reaction is carried out. If the reaction is carried out with one equivalent of the silyllithium reagent at $-78{ }^{\circ} \mathrm{C}$, and the intermediate 2 quenched at $-78{ }^{\circ} \mathrm{C}$, the products are acylsilanes $3 .^{1}$ If the same reaction is carried out at $-78{ }^{\circ} \mathrm{C}$ but the mixture warmed to $-20{ }^{\circ} \mathrm{C}$ before quenching, the product is an enediamine $4 .^{2}$ If two equivalents of the silyllithium reagent are used, and the mixture quenched at $-20^{\circ} \mathrm{C}$, the product is an $\alpha$-silylalkyl- $N, N$-dimethylamine $5^{3}$

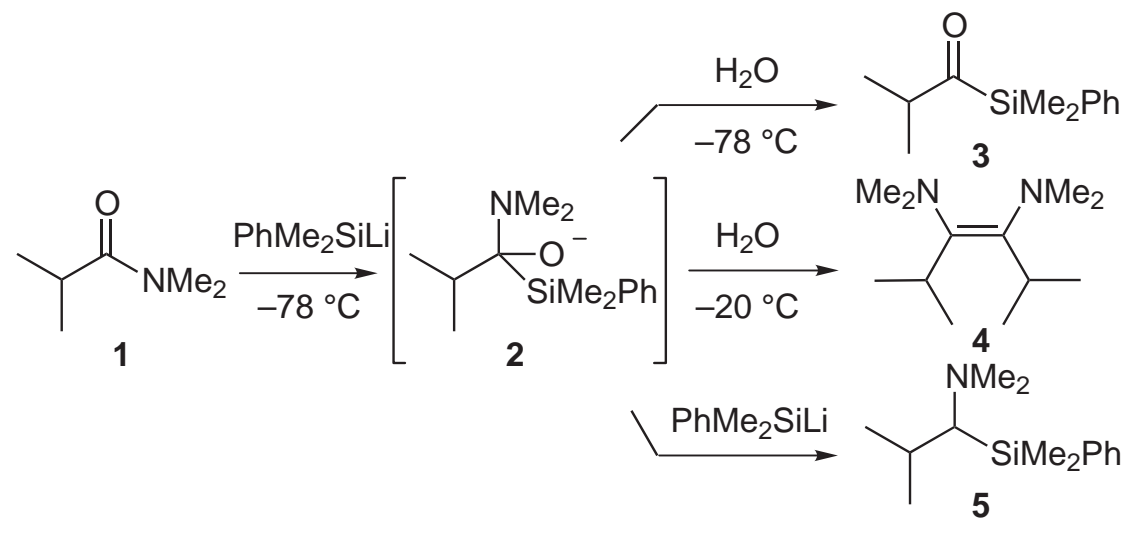


The pathway for the second and third reactions appears to involve a carbene or carbene-like species formed by a Brook rearrangement of the first-formed tetrahedral intermediate 2 followed by loss of the silyloxy substituent. At the lower temperature, the Brook rearrangement appears not to have taken place, and the tetrahedral intermediate simply loses the dimethylamino group in the usual way, once it is in a protic medium.

In this paper we describe what happens when $N, N$-dimethylthioamides are treated with the dimethyl(phenyl)silyllithium reagent. We were intrigued by the uncertainty whether the analogous Brook-rearranging step in the thioamide series $6 \rightarrow 7$ would be effectively easier or harder. Formulating the Brook rearrangement for simplicity as an equilibrium between a thioanion 6 and a carbanion 7, we could see that the carbanion would be better stabilised in the thioamide series than in the amide series. On the other hand, the thioanion would be less nucleophilic towards the silicon atom. One precedent for a thia-analogue of the Brook rearrangement appears to suggest that the rearrangement is not as easy with a thioanion as it is with an oxyanion. ${ }^{4}$

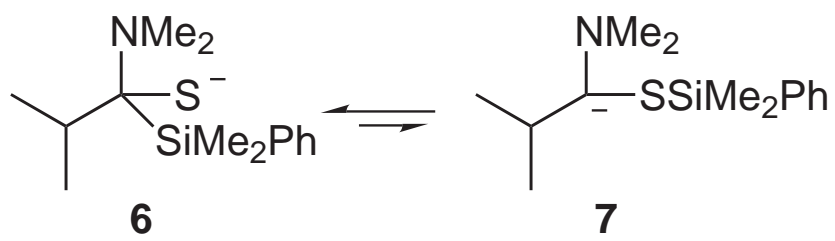

\section{Results and Discussion}

We found that in each case that we looked at, the only reaction between dimethyl(phenyl)silyllithium and the thioamides 8a-d, typically carried out at $-78{ }^{\circ} \mathrm{C}$ with one equivalent of the silyllithium reagent in THF, is the displacement of the amine group, and the formation of thioacylsilanes 9, seen as fleeting blue-purple colours when the reaction mixture was quenched. We isolated the enethiol tautomers 10a-d, unsurprisingly, since it is well established that thioacylsilanes are usually fully "enolised", 5,6

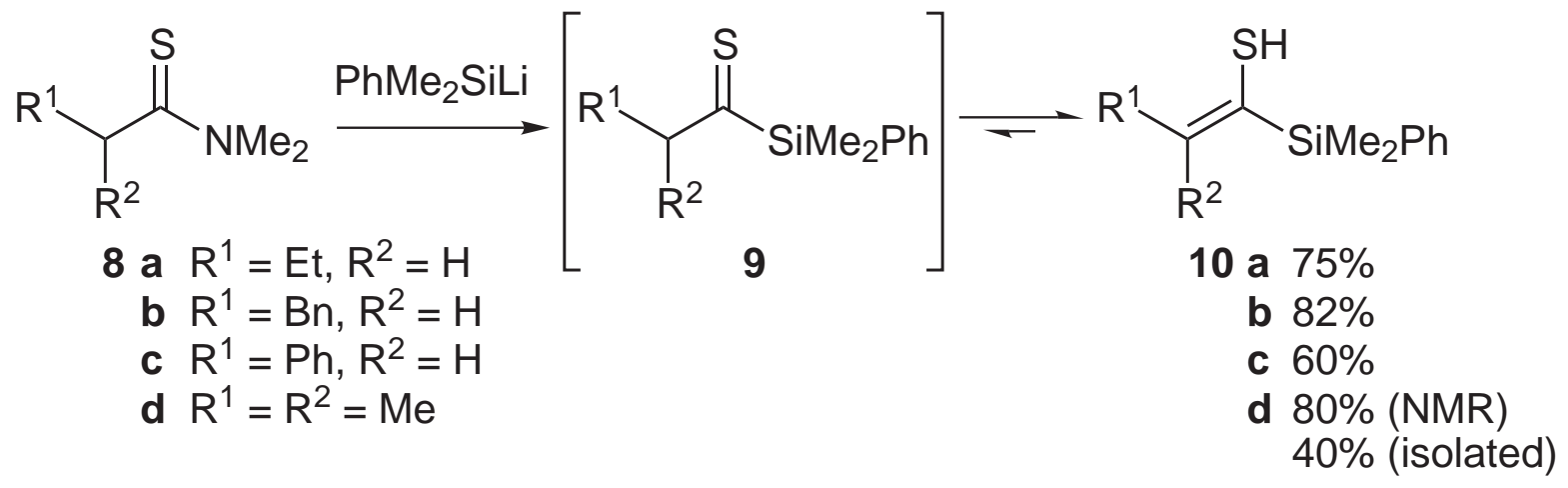


The thioamides were prepared either by treating the corresponding amide with Lawesson's reagent $^{7}$ in refluxing toluene (for $\mathbf{8 d}$ ), or using microwave technology and the solid-supported thionating agent developed by Ley and his co-workers (for 8a-c). ${ }^{8}$ We also tried other reaction conditions, using higher temperatures or larger quantities of the silyllithium reagent, but the results were essentially the same. Any excess of silyllithium reagent gave us greater problems separating the enethiols from the inevitable disiloxane by-products, which inconveniently ran at similar rates on chromatography columns, and is responsible for the losses in the isolation of the product 10d.

Our route to acylsilanes works reasonably well. It is similar to the route developed by Bonini and her co-workers $\mathbf{1 1} \rightarrow \mathbf{1 2} \rightarrow \mathbf{1 3}^{5,6}$ In essence, ours carries out their two steps, treatment with a silyl nucleophile and introduction of sulfur, in the opposite order. In the only one of our four reactions common to both methods $(\mathbf{8 a} \rightarrow \mathbf{1 0 a})$, our yield was comparable to theirs, but our route avoids using copper or the relatively sensitive acylsilane, which may occasionally have advantages.

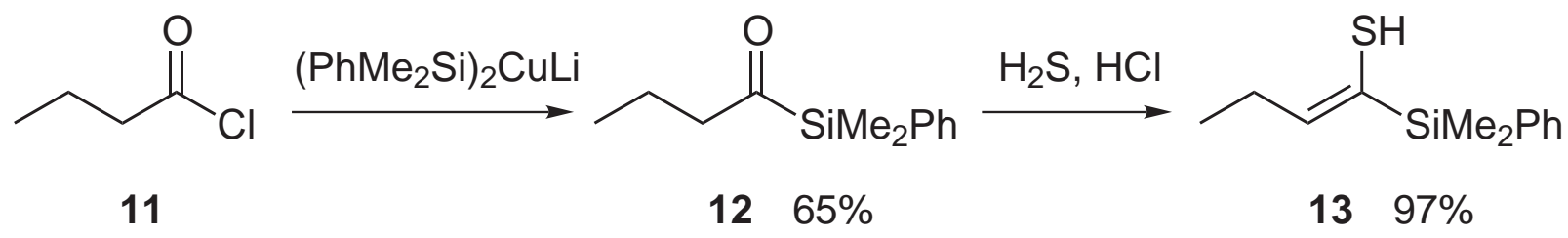

We also carried out the reaction with the cyclopropyl $N, N$-dimethylthioamide, but obtained a mixture of products that appeared to be the same as that Bonini and her co-workers had found: the purple acylsilane, a ring-opened butenethiol, and a silylated dihydrothiophene. ${ }^{9}$

Only when we carried out the reaction using two equivalents of methyl(diphenyl)silyllithium did we see any product that had undergone a Brook rearrangement. The thioamide 8d gave a detectable trace of the $\alpha$-silylamine 14, the normal product under these conditions from ordinary amides, and of which we had an authentic sample. The presence of two phenyl groups on the silicon atom is known to encourage Brook rearrangement. ${ }^{10}$ We conclude that the thia-Brook rearrangement is not as easy as the usual oxa-Brook rearrangement.

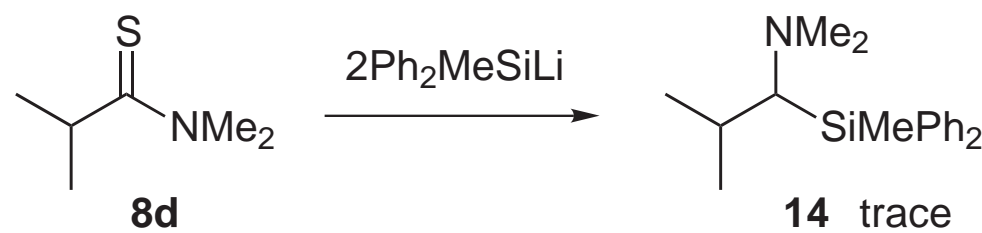




\section{Experimental Section}

Thioamides 8a-8c and $N, N$-Dimethylcyclopropanecarbothioamide. These were prepared by the method described in ref. 5, and supplied to us.

$\boldsymbol{N}, \boldsymbol{N}, 2$-Trimethylpropanethioamide (8d). $N, N, 2$-Trimethylpropanamide $(2.16 \mathrm{~g}, 18.8 \mathrm{mmol})$ and Lawesson's reagent $(4.75 \mathrm{~g}, 11.7 \mathrm{mmol})$ were stirred in dry toluene $\left(15 \mathrm{~cm}^{3}\right)$ at $110{ }^{\circ} \mathrm{C}$ under argon for $10 \mathrm{~h}$. Toluene was removed under reduced pressure and an initial crude distillation gave the thioamide ${ }^{11}$ as a yellow oil $(525 \mathrm{mg}, 21 \%)$ bp $62{ }^{\circ} \mathrm{C} / 0.3 \mathrm{mmHg}$. The remaining crude mixture was chromatographed [EtOAc-light petroleum (bp 40-60 ${ }^{\circ} \mathrm{C}$ ), 1:19] to give a second crop of the thioamide $(1.38 \mathrm{~g}$, total $1.91 \mathrm{~g}, 77 \%) ; R_{\mathrm{f}}$ [EtOAc-light petroleum $\left(\mathrm{bp} 40-60{ }^{\circ} \mathrm{C}\right), 3: 7$ ] $0.31 ; v_{\max }($ film $) / \mathrm{cm}^{-1} 1508(\mathrm{~N}-\mathrm{C}=\mathrm{S}), 1277(\mathrm{~N}-\mathrm{C}=\mathrm{S}) ; \delta_{\mathrm{H}}\left(400 \mathrm{MHz} ; \mathrm{CDCl}_{3}\right) 3.47(3 \mathrm{H}, \mathrm{s}$, $\left.\mathrm{NMe}_{\mathrm{A}} \mathrm{Me}_{\mathrm{B}}\right), 3.33\left(3 \mathrm{H}, \mathrm{s}, \mathrm{NMe}_{\mathrm{A}} M e_{\mathrm{B}}\right), 3.13(1 \mathrm{H}$, septet, $J$ 6.5, $\mathrm{CHMe}$ ) and $1.20(6 \mathrm{H}, \mathrm{d}, J$ 6.5, $\mathrm{CHMe}_{2}$.

\section{General procedure for the preparation of the enethiols 10a-10d}

Dimethyl(phenyl)silyllithium ( $1 \mathrm{~mol} \mathrm{dm}{ }^{-3}$ in THF, $\left.1.1 \mathrm{~cm}^{3}\right)$ was added slowly to a stirred solution of the thioamide $8(1 \mathrm{mmol})$ in dry THF $\left(2 \mathrm{~cm}^{3}\right)$ at $-78{ }^{\circ} \mathrm{C}$ under argon. After 10 $40 \mathrm{~min}$, the reaction was quenched with saturated aqueous ammonium chloride solution. The organic layer was separated, and the aqueous layer extracted with ether. The organic extracts were combined, dried $\left(\mathrm{MgSO}_{4}\right)$, and concentrated under reduced pressure to give an oil, which was chromatographed (typically $\mathrm{Et}_{2} \mathrm{O}$-hexane, 20:80) to yield the $\alpha$-silyl enethiol 10.

1-[Dimethyl(phenyl)silyl]-1-butene-1-thiol ${ }^{6}$ (10a). (75\% with $13 \%$ of recovered thioamide) as a yellow oil; $R_{\mathrm{f}}\left(\mathrm{Et}_{2} \mathrm{O}-\right.$ hexane, 20:80) 0.64; $v_{\max }\left(\right.$ film) $/ \mathrm{cm}^{-1} 2563(\mathrm{SH}), 1589(\mathrm{C}=\mathrm{C}), 1248$ $\left(\mathrm{SiMe}_{2}\right)$ and $1110(\mathrm{SiPh}) ; \delta_{\mathrm{H}}\left(250 \mathrm{MHz} ; \mathrm{CDCl}_{3}\right) 7.58-7.54(2 \mathrm{H}, \mathrm{m}, o-\mathrm{PhSi}), 7.40-7.37(3 \mathrm{H}, \mathrm{m}$, $m$ - and p-PhSi), $5.95(1 \mathrm{H}, \mathrm{t}, J$ 6.5, $\mathrm{C}=\mathrm{CH}), 2.48(1 \mathrm{H}, \mathrm{s}, \mathrm{SH}), 2.23\left(2 \mathrm{H}\right.$, quintet, $J$ 7.1, $\left.\mathrm{CH}_{2}\right)$, $1.05\left(3 \mathrm{H}, \mathrm{t}, J\right.$ 7.5, Me) and $0.44\left(6 \mathrm{H}, \mathrm{s}, \mathrm{SiMe}_{2}\right)$.

1-[Dimethyl(phenyl)silyl]-3-phenyl-1-propene-1-thiol (10b). (82\% with $13 \%$ of recovered thioamide) as a yellow oil; $R_{\mathrm{f}}\left(\mathrm{Et}_{2} \mathrm{O}\right.$-hexane, 20:80) 0.63; $v_{\max }($ film $) / \mathrm{cm}^{-1} 2560(\mathrm{SH}), 1587$ $(\mathrm{C}=\mathrm{C}), 1248\left(\mathrm{SiMe}_{2}\right)$ and $1113(\mathrm{SiPh}) ; \delta_{\mathrm{H}}\left(250 \mathrm{MHz} ; \mathrm{CDCl}_{3}\right) 7.59-7.55(2 \mathrm{H}, \mathrm{m}, \mathrm{Ph}), 7.40-$ $7.22(8 \mathrm{H}, \mathrm{m}, \mathrm{Ph}), 6.15\left(1 \mathrm{H}, \mathrm{t}, J\right.$ 6.7, C=CH), $3.58\left(2 \mathrm{H}, \mathrm{d}, J\right.$ 6.7, $\left.\mathrm{PhCH}_{2}\right), 2.59(1 \mathrm{H}, \mathrm{s}, \mathrm{SH})$ and $0.46\left(6 \mathrm{H}, \mathrm{s}, \mathrm{SiMe}_{2}\right) ; \delta_{\mathrm{C}}\left(\mathrm{CDCl}_{3}\right) 139.6+, 138.2-, 136.0+, 133.9-, 129.3-$, 128.3- (large signal, possibly two different carbons), 127.8-, 125.9-, 36.8 $+\left(\mathrm{CH}_{2} \mathrm{Ph}\right)$ and $-3.2-\left(\mathrm{SiMe}_{2}\right) ; \mathrm{m} / \mathrm{z}(\mathrm{ESI})$ $307\left(47 \%, \mathrm{MNa}^{+}\right.$) and 303 (100\%) (Found: $\mathrm{MNa}^{+}, 307.09480 . \mathrm{C}_{17} \mathrm{H}_{20} \mathrm{NaSSi}$ requires $M N a$, 307.09526).

1-[Dimethyl(phenyl)silyl]-2-phenyl-1-ethene-1-thiol (10c). $(60 \%$ with $12 \%$ of recovered thioamide) as a pale yellow oil; $R_{\mathrm{f}}\left(\mathrm{Et}_{2} \mathrm{O}\right.$-hexane, 20:80) 0.64; $v_{\max }(\mathrm{film}) / \mathrm{cm}^{-1} 2550(\mathrm{~S}-\mathrm{H}), 1585$ $(\mathrm{C}=\mathrm{C}), 1249\left(\mathrm{SiMe}_{2}\right)$ and $1114(\mathrm{SiPh}) ; \delta_{\mathrm{H}}\left(250 \mathrm{MHz} ; \mathrm{CDCl}_{3}\right)$ 7.62-7.60 $(2 \mathrm{H}, \mathrm{m}, \mathrm{Ph}), 7.54-7.51$ $(2 \mathrm{H}, \mathrm{m}, \mathrm{Ph}), 7.42-7.35$ (6 H, m, Ph) $6.86(1 \mathrm{H}, \mathrm{s}, \mathrm{C}=\mathrm{CH}), 2.96(1 \mathrm{H}, \mathrm{s}, \mathrm{SH})$ and $0.56(6 \mathrm{H}, \mathrm{s}$, $\left.\mathrm{SiMe}_{2}\right) ; \delta_{\mathrm{C}}\left(\mathrm{CDCl}_{3}\right) 137.2+, 135.7+, 135.3-, 134.1-, 130.3+, 129.5-, 128.6-, 128.0-, 127.8-$, 127.0- and -3.3-; m/z (EI) $270\left(9 \%, \mathrm{M}^{+}\right) 192$ (89\%) and 135 (100\%, $\left.\mathrm{PhMe}_{2} \mathrm{Si}\right)$ (Found: $\mathrm{M}^{+}$, 
270.08892. $\mathrm{C}_{16} \mathrm{H}_{18} \mathrm{SSi}$ requires $\left.M, 270.08985\right)$.

1-[Dimethyl(phenyl)silyl]-2-methyl-1-propene-1-thiol (10d). (40\% isolated, $80 \%$ by NMR together with $16 \%$ of thioamide) as an oil; $R_{\mathrm{f}}\left[\mathrm{CH}_{2} \mathrm{Cl}_{2}\right.$-light petroleum (bp 40-60 $\left.\left.{ }^{\circ} \mathrm{C}\right), 1: 4\right]$ 0.39; $v_{\max }($ film $) / \mathrm{cm}^{-1} 2572(\mathrm{~S}-\mathrm{H}), 1583(\mathrm{C}=\mathrm{C}), 1251\left(\mathrm{SiMe}_{2}\right)$ and $1104(\mathrm{SiPh}) ; \delta_{\mathrm{H}}\left(400 \mathrm{MHz} ; \mathrm{CDCl}_{3}\right)$ 7.57-7.53 (2 H, m, o-PhSi), 7.39-7.34 (3 H, m, $m$ - and p-PhSi), $2.66(1 \mathrm{H}, \mathrm{s}, \mathrm{SH}), 1.92(3 \mathrm{H}, \mathrm{s}$, $\left.\mathrm{CMe}_{\mathrm{A}} \mathrm{Me}_{\mathrm{B}}\right), 1.78\left(3 \mathrm{H}, \mathrm{s}, \mathrm{CMe}_{\mathrm{A}} M e_{\mathrm{B}}\right)$ and $0.51\left(6 \mathrm{H}, \mathrm{s}, \mathrm{SiMe}_{2}\right) ; \delta_{\mathrm{C}}\left(\mathrm{CDCl}_{3}\right) 144.5+, 138.7+$, 133.8- $(\mathrm{CH}), 129.2-(\mathrm{CH}), 128.0-(\mathrm{CH}), 118.5+, 25.5-\left(\mathrm{CMe}_{\mathrm{A}} \mathrm{Me}_{\mathrm{B}}\right), 23.8-\left(\mathrm{CMe}_{\mathrm{A}} \mathrm{Me} e_{\mathrm{B}}\right)$ and 0.26- $\left(\mathrm{SiMe}_{2}\right) ; \mathrm{m} / \mathrm{z}$ (EI) $222\left(2 \%, \mathrm{M}^{+}\right)$and $135\left(100 \%, \mathrm{SiMe}_{2} \mathrm{Ph}\right)$ (Found: $\mathrm{M}^{+}, 222.0891$. $\mathrm{C}_{12} \mathrm{H}_{18} \mathrm{SSi}$ requires $\left.M, 222.0899\right)$.

Cyclopropyl[dimethyl(phenyl)silyl]methanethione9. As a purple fraction showing $v_{\max }($ film $) / \mathrm{cm}^{-1} 1249\left(\mathrm{SiMe}_{2}\right), 1222(\mathrm{C}=\mathrm{S})$ and $1114(\mathrm{SiPh}) ; \delta_{\mathrm{H}}\left(400 \mathrm{MHz} ; \mathrm{CDCl}_{3}\right)$ 7.68-7.56 (2 $\mathrm{H}, \mathrm{m}, \mathrm{PhSi}), 7.41-7.26$ (3 H, m, PhSi), 3.66 (1 H, m, CHC=S), $1.46\left(2 \mathrm{H}, \mathrm{m}, \mathrm{CH}_{2}\right), 1.18$ (2 H, m, $\left.\mathrm{CH}_{2}\right)$ and $0.55\left(6 \mathrm{H}, \mathrm{s}, \mathrm{SiMe}_{2}\right)$, contaminated with a ring-opened by-product 4-X-1[dimethyl(phenyl)silyl]-1-butene-1-thiol ${ }^{9}$. (the identity of $\mathrm{X}$ is not certain); $\delta_{\mathrm{H}}(400 \mathrm{MHz}$; $\left.\mathrm{CDCl}_{3}\right)$ 7.50-7.27 (5 H, m, SiPh), 6.10-6.05 (1 H, m, HC=CSH), 2.45-2.37 (4 H, m, $\left.\mathrm{CH}_{2}\right)$ and $0.40\left(6 \mathrm{H}, \mathrm{s}, \mathrm{SiMe}_{2}\right)$. A later fraction matched the data for 4,5-dihydro-2thiophenyl(dimethyl)phenylsilane ${ }^{9} . \delta_{\mathrm{H}}\left(400 \mathrm{MHz} ; \mathrm{CDCl}_{3}\right)$ 7.67-7.28 $(5 \mathrm{H}, \mathrm{m}, \mathrm{SiPh}), 5.8(1 \mathrm{H}$, t, $\mathrm{CH}=\mathrm{CS}), 3.2\left(2 \mathrm{H}, \mathrm{t}, \mathrm{CH}_{2} \mathrm{~S}\right), 2.7\left(2 \mathrm{H}, \mathrm{m}, \mathrm{CH}_{2}\right)$ and $0.5\left(6 \mathrm{H}, \mathrm{s}, \mathrm{SiMe}_{2}\right)$.

Reaction of methyl(diphenyl)silyllithium with the thioamide 8d. This reaction was carried out in the same way as the general procedure, except that two equivalents of the methyl(diphenyl)silyllithium reagent were used, and the aqueous work-up was for basic product. The basic products showed the characteristic signals of N,N,2-trimethyl-1[methyl(diphenyl)silyl]-1-propanamine ${ }^{12}(\mathbf{1 4})$ in trace amounts: $\delta_{\mathrm{H}}\left(200 \mathrm{MHz} ; \mathrm{CDCl}_{3}\right) 7.80-7.66$ (4 H, m, o-Ph), 7.50-7.38 (6 H, m, m- and p-Ph), 2.67 (1 H, d, J 6, CHN), 2.50 (6 H, s, NMe $)_{2}$, $2.22(1 \mathrm{H}$, dseptet, $J 6.5$ and 6, CHMe $), 1.02\left(3 \mathrm{H}, \mathrm{d}, J\right.$ 6.5, $\left.\mathrm{CHMe}_{\mathrm{A}} \mathrm{Me}_{\mathrm{B}}\right), 0.99$ (3 H, d, J 6.5, $\left.\mathrm{CHMe}_{\mathrm{A}} \mathrm{Me} \mathrm{B}_{\mathrm{B}}\right)$ and $0.86(3 \mathrm{H}, \mathrm{s}, \mathrm{SiMe})$.

\section{Acknowledgements}

We thank the EPSRC for a maintenance award (MB), and Ian Storer for supplying some of the thioamides.

\section{References}

1. Fleming, I.; Ghosh, U. J. Chem. Soc., Perkin Trans. 1 1994, 257-262.

2. Fleming, I.; Ghosh, U.; Mack, S. R.; Clark, B. P. Chem. Commun. 1998, 711.

3. Fleming, I.; Mack, S. R.; Clark, B. P. Chem. Commun. 1998, 713.

4. Wright, A.; Ling, D.; Boudjouk P.; West, R. J. Am. Chem. Soc. 1972, 94, 4784. 
5. Bonini, B. F.; Comes-Franchini, M.; Fochi, M.; Mazzanti, G.; Ricci, A. Tetrahedron 1996, 52, 4803.

6. Bonini, B. F.; Comes-Franchini, M.; Fochi, M.; Mazzanti, G.; Peri, F.; Ricci, A. J. Chem. Soc., Perkin Trans. 1 1996, 2803.

7. Cava, M. P.; Levinson, M. I. Tetrahedron 1985, 41, 5061.

8. Ley, S. V.; Leach, A. G.; Storer, R. I. J. Chem. Soc., Perkin Trans. 1 2001, 358.

9. Bonini, B. F.; Busi, F.; de Laet, R. C.; Mazzanti, G.; Thuring, J. W. J.-F.; Zani, P.; Zwanenburg, B. J. Chem. Soc., Perkin Trans. 1 1993, 1011.

10. Brook, A. G.; LeGrow, G. E.; MacRae, D. M. Can. J. Chem. 1967, 45, 239.

11. Fritz, H.; Hug, P.; Lawesson, S. O.; Logemann, E.; Pedersen, B. S.; Sauter, H.; Scheibye, S.; Winkler, T. Bull. Soc. Chim. Belg. 1978, 87, 525.

12. Mack, S. R. PhD Thesis: Cambridge, 1997; p 187. 